$$
\begin{aligned}
& \text { قسم الانتاج الحيواني }
\end{aligned}
$$

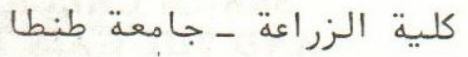

$$
\begin{aligned}
& \text { رئيس القسم : أ •د/ سـعيد محمود }
\end{aligned}
$$

مستوى الكالسيوم والفوسفور الغير عضوي والعلاقة بينهما ومعدل الزيادة في الوزن لعجول وعجلات الفريزيان من الولادة وحتي سن البلوغ

$$
\text { راوية الحلواني ، فكري القربي ، عبدالسلام متولي }
$$

استخدم في هذا البحث عدد ثلاثون عجل وعجلة من سلالة الفريزيان ( 10 نكور ، 10

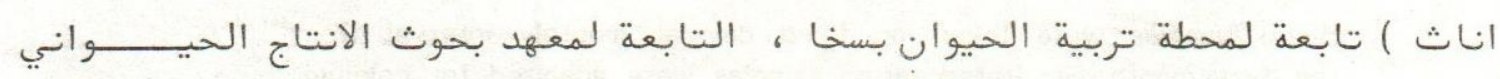
• بوزارة الزراعة

أخذت عينات الدم شهريا في يوم محدد وحتى عمر 1 | شهر وقد قدر تركيز كـل مســـن

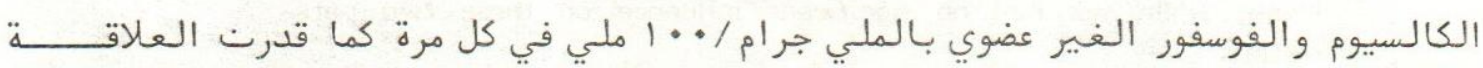

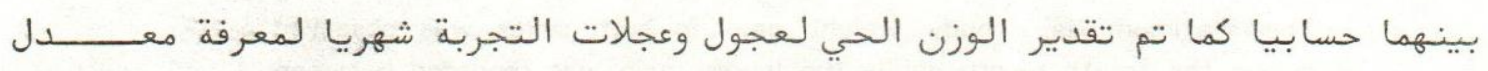
• مالزيادة في الوزن

وقد أوضحت النتائج أن عمر الحيوان له تأثير معنوي على مستوى كل من الكالســــيوم

والفوسفور الغير عضوي في الدم بنينما كان لجنس الحيوان تأثير غير معنوي على كليهما وكان معدل الزيادة في الوزن أعلى ما يمكن في الفترة بين الشهر الثالث والرابع من العمر وكان أقل مستوى في الشهور التي تلت الفطام ثم بـأ معدل الزيادة بعد نلك فـــي الارتفاع حتى ومل أقصى قيمة في نهاية التجربة ( سر ا كجم /يوميا ) كا أوضحت التجربه

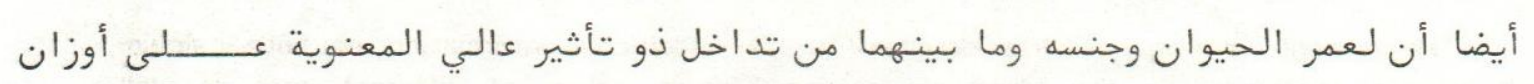
عجول الفريزيان • كما لوحظ أيضا أن هناك معنويه عالية لمعدل الزيادة في الوزن في كـلـ شهر من العمر والذي يليه 
Dept. of Animal Production,

Faculty of Agric., Tanta University,

Head of Dept. Prof. Dr. S.A. Mahmoud.

\title{
SERUM CALCIUM, INORGANIC PHOSPHORUS LEVELS AND THE GAIN IN BODY WEIGHT OF FRIESIAN CALVES FROM BIRTH TILL MATURITY \\ (With 4 Tables and 3 Figures)
}

\author{
By \\ RAWIA, S. EL-HALAWANY; F. EL-KERABY* \\ and ABD-EL-SALAM METWALLY \\ (Received at 21/10/1986)
}

\begin{abstract}
SUMMARY
Thirty clinical normal Friesian calves (15 males and 15 females) were used in this study to reveal th: effect of animal age and sex on serum calcium, inorganic phosphorus levels as well as the relationship of the two parameters with the daily body weight gain.

Blood samples were taken on fixed day at monthly interval from the first month. Separated serum samples were analysed for calcium, inorganic phosphorus and $\mathrm{Ca}$; ph ratio was recorded. Body weight of the calves was recorded monthly untill the end of the experimental period. The obtained results concluded that animal age has a sinificant effect on blood calcium, and inorganic phosphorus levels, while sex had no significant influence on these two parameters.

The maximum daily body weight gain in both sexes was observed during the fourth month, while the lowest gain was recorded between 5-7 months of age, then tend to be increased with the advance of age till reaches $1.03 \mathrm{Kg}$. gain at 18 months of age.
\end{abstract}

\section{INTRODUCTION}

It is well known that blood analysis of pregnant animals reflects the nutritional provision for the foetus; as well as throwing some light upon the food requirements of the dam during this critical period of life.

During the early life of calves drastic metabolic changes occur leading to alteraions in the concentration of many blood components, the most important of these components are the calcium and phosphorus levels.

The present investigation was designed to give additional information on both calcium and inoganic phosphorus in the blood of growing Friesian calves at different ages as well as to explain the relationship of these parameters with the gain in body weight at various stages of growth.

\section{MATERIAL and METHODS}

Thirty clinicaly normal Friesian calves ( 15 males and 15 females) were used in this experiment. The calves belongs to Sakha Breeding Station, Animal Production Research Institute, Minitry of Agriculture. 
RAWIA, S. EL-HALAWANY, et al.

The feeding system from weaning ( 15 weeks old) to 18 months of age was done according to the body weight of the calves as table 1 .

Table (1):

Quantities of concentrates mixture and roughage given to the calves

\begin{tabular}{llll}
\hline $\begin{array}{l}\text { Live body weight } \\
\text { of the calves }\end{array}$ & $\begin{array}{l}\text { Con. } \\
\text { mix. }\end{array}$ & $\begin{array}{l}\text { Rice } \\
\text { straw }\end{array}$ & Hay \\
\hline Less than $150 \mathrm{Kg}$ & 2.75 & 1.5 & 1.5 \\
From 150 to $200 \mathrm{Kg}$ & 3.50 & 2.0 & 1.5 \\
* From 200 to $300 \mathrm{Kg}$ & & & \\
From 300 to $350 \mathrm{Kg}$ & 5.00 & 3.0 & 1.5 \\
\hline
\end{tabular}

* During this period calves fed green fodder (Berseem) ad-libitum. Concentrate mixture consisted of $35 \%$ cotton seed, $33 \%$ wheat bran, $22 \%$ yellow maize, $4 \%$ rice starch residue, $3 \%$ molases, $2 \%$ lime-stone and $1 \%$ salt.

Blood samples were taken on fixed day at monthly interval. Samples were collected via the jugular vein using minimum restrain. Collected blood samples were allowed to clot and separation of clear blood serum has been carried out after centrifugation at $3000 \mathrm{r} \cdot \mathrm{p} . \mathrm{m}$. for $20 \mathrm{~min}$. Separated serum was transferred carefully to another clean dry and sterile vial then analysis was adopted thereafter. Blood serum calcium $(\mathrm{mg} / 100 \mathrm{ml})$ was determined using reverse titration method using calcium as indicator according to the method described by BARON and BELL (1957). Blood serum inorganic phosphorus $(\mathrm{mg} / 100 \mathrm{ml}$ ) was determined according to the colorimetric method described by GOMORRI (1942).

Body weight of each calf was recorded monthly until the end of the experimental period. Data obtained for each parameter measured were arranged in factorial order in a completely randomized design, then analysed statistically according to the method described by SNEDECOR (1961). Comparisons between individual means for different months were carried out using Duncan multiple range test (DUNCAN, 1955).

\section{RESULTS}

The mean values of serum calcium, inorganic phosphorus $(\mathrm{mg} / \mathrm{ml})$ and Ca: Ph ratio as affected by age and sex of the calves are included in table 2, Fig. 1 and 2 .

\section{DISCUSSION}

It was evident that the minimum level of blood serum calcium was observed in male and female calves at the first month of age $(8.3$ and $7.7 \mathrm{mg} \%$, respectively)? Highest levels of this parameter in male calves $(11.6 \mathrm{mg} \%$ ) were recorded at 6 months and 15 months of age. In females the maximum value was $12.2 \mathrm{mg} \%$ and recorded at 15 months old. No. significant trend was found for changes in serum calcium concentration with age. The obtained results concerning the levels of these parameters in the calves are in agreement with the data published by KITCHENHAM et al. (1975) and MANSTON et al. (1977).

It was evident also that sex of the calves had no significant influence on serum calcium level, however there was tendency of irregular increase in the blood serm calcium level as age of the calves advanced.

Assiut Vet.Med.J. Vol. 18, No. 36, 1987. 
Regarding the serum inorganic phosphorus level, it was evident that sex had no significant effect on the level of either calcium or inorganic phosphorus or the ratio between the two parameters. There were flactuations in serum inorganic phosphorus level as age of the animal advanced, however, tie monthly variations were approximately similar with those obtained by KITCHENHAM et al. (975) and KARRAM (1978).

The obtained data indicated positive significant correlation $(r=0.331)$ between those two parameters $(P / \ldots 0.01)$. Table 2 also illustrate the calcium and inorganic phosphorus ratio in male and female calves at different ages. It was evident that in male and female calves the wide ratio of the two parameters was noiced at 12 months of age, while a narrow ratio in male and female calves was observed at 16 and 15 months of age, respectively. It was concluded from the results that the close correlation between calcium and inorganic phosphorus was markedly apparent at one year old. This could be attributed to the changes in the hormone activation in this transit period of live. Similar results were also obtained by DALTON (1967) and TUMBLESON et al. (1973).

Table 3 summarizes the daily body weight gain for male and female calves throughout the experimental period. The highest gain in the body weight of male and female calves was recorded at 18 months of age. Male calves always recorded heavier weight than female and this was maintained throughout the whole experimental period. The differences between males and females in body weight gain were statistically significant. The mean weight gain overall the experimental period for both sexes was $0.62 \mathrm{Kg} /$ day. Similar values have been reported in Friesian calves by KASSAB (1964), ROY (1970), AFIFI and SOLIMAN (1971) and ALIM and TAHER (1979).

It was evident from table 4 that the highest correlation between body weight and calcium level was noticed at the 12 and 8 months of age in both male and female calves, while the highest correlation between body weight and inorganic phosphorus was recorded at 8 and 14 months of age in male and female calves, respectively.

Although fluctuation occurred in the blood components throughout the first twelve months of life, the most characteristic changes occurred between the five and nine months of age. These changes may be considered to be associated with approach of onset of puberty and with the changes in the growth rats.

\section{REFERENCES}

Afifi, Y.A. and Soliman, A.M. (1971): Sources of variation in birth weigh and weaning weight of Friesian calves. Agric. Res. Rev. U.A.R. 49: 1.

Alim, K.A. and Taher, A. (1979): The performance of Friesian and buffaloe calves. J. of Animal Pro. 15: 71.

Baron, D.M. and Bell, J.L. (1957): Determination of calcium in blood serum. Clin. Chim. Acta, 2: 327.

Dalton, R.G. (1967): Variations in calf plasma composition with age. Brit. Vet. J. $123: 48$. Duncan, D.B. (1955): Multiple range and multiple "F" test. Biometrics, 11: 1.

Comorri, G. (1942): Determination of blood inorganic phosphorus. J. Lab. Clin. Med., 27 : 955. Karram, M.H. (1978): Some haematological and biochemical studies in buffaloe calves up to 6 months. M. Vet. Sci. Thesis, Fac. of Vet. Med., Assiut Univ.

Kassab, S.A. (1964): On maternal and some other influences or birth weight and hair coat in two Dutch cattle breed. Thesis Dect. Agric. Sci., Agric. Univ. Waeningen.

Kitchenham, B.A., Rowlands, G.J., Manston, R. and Baldry, A.F. (1975): The blood composition of dairy calves reared under conventional and rapid-growth systems. Brit. Vet. J. $131: 436$. 


\section{RAWIA, S. EL-HAL.AWANY, et al.}

Manston, R.; Kitchenham, B.A. and Baldry, A.F. (1977): The influence of system of husbandry upon the blood composition of bulls and steers reared for beef production. Brit. Vet. J. 133: 37.

Roy, J.H.B. (1970): "The calf": Management and feeding. Volume 1, London, Life Books Ltd. Snedecor, G.W. (1961): "Staistical methods" Sth ed. Ames, lowa, lowa State College Press.

Tumbleson, M.E., Wingfield, W.E., Johnson, H.D., Cambell, J. and Middleton, C. (1973): Serum electrolyte concentrations as a function of age, in female dairy cattle Aging and serum electrolytes. Cornel, Vet. 63: 58-64.

Table (2)

Means and standard orrors of serum calcium, inorganic phosphorus and $\mathrm{Ca}$. P. ratio an affected by animal ae and sex

\begin{tabular}{|c|c|c|c|c|c|c|c|c|}
\hline \multirow[b]{2}{*}{$\begin{array}{l}\text { Age } \\
\text { No. }\end{array}$} & \multicolumn{3}{|c|}{ Serum calcium $(\mathrm{mg} / 100 \mathrm{ml})$} & \multicolumn{3}{|c|}{ Inorganic phonphorus $(\mathrm{mg} / 100 \mathrm{ml}$ ) } & \multicolumn{2}{|c|}{ Ca : ph ratio } \\
\hline & Male & Female & Overall & Male & Female & Overall & Male & Female \\
\hline 1 & $8.3 \pm 0.35$ & $7.7 \pm 0.28$ & $8.0 \pm 0.239$ & $5.8 \pm 0.23$ & $5.3 \pm 0.28$ & $5.5 \pm 0.05$ & $1.4: 1$ & $1.5: 1$ \\
\hline 2 & $9.7 \pm 0.30$ & $9.4 \pm 0.25$ & $9.6 \pm 0.20^{h}$ & $6.0 \pm 0.25$ & $6.4 \pm 0.33$ & $6.21 \pm 0.21^{i}$ & $1.6: 1$ & $1.5: 1$ \\
\hline 3 & $10.2 \pm 0.38$ & $10.3 \pm 0.35$ & $10.2 \pm 0.263$ & $7.3 \pm 0.38$ & $7.3 \pm 0.30$ & $7.3 \pm 0.244$ & $1.4: 1$ & $1.3: 1$ \\
\hline 4 & $10.6 \pm 0.35$ & $10.08 \pm 0.43$ & $10.7 \pm 0.278$ & $8.1 \pm 0.30$ & $8.4 \pm 0.33$ & $8.3 \pm 0.22$ & $1.3: 1$ & $1.3: 1$ \\
\hline 5 & $11.2 \pm 0.33$ & $11.6 \pm 0.30$ & $11.4 \pm 0.224$ & $8.3 \pm 0.17$ & $8.7 \pm 0.17$ & $8.5 \pm 0.128$ & $1.4: 1$ & $1.3: 1$ \\
\hline 6 & $11.6 \pm 0.25$ & $12.0 \pm 0.25$ & $11.8 \pm 0.184$ & $8.3 \pm 0.10$ & $8.3 \pm 0.21$ & $8.3 \pm 0.116$ & $1.4: 1$ & $1.4: 1$ \\
\hline 7 & $10.9 \pm 0.41$ & $11.5 \pm 0.35$ & $11.2 \pm 0.277$ & $8.3 \pm 0.23$ & $8.5 \pm 0.18$ & $8.4 \pm 0.142$ & $1.3: 1$ & $1.4: 1$ \\
\hline 8 & $10.4 \pm 0.38$ & $10.5 \pm 0.44$ & $10.4 \pm 0.283$ & $7.8 \pm 0.17$ & $7.9 \pm 0.25$ & $7.9 \pm 0.152$ & $1.3: 1$ & $1.3: 1$ \\
\hline 9 & $10.8 \pm 0.28$ & $9.6 \pm 0.30$ & $10.2 \pm 0.237$ & $7.9 \pm 0.23$ & $7.5 \pm 0.30$ & $7.9 \pm 0.193$ & $1.3: 1$ & $1.3: 1$ \\
\hline 10 & $11.6 \pm 0.36$ & $11.6 \pm 0.33$ & $11.6 \pm 0.249$ & $7.8 \pm 0.28$ & $8.3 \pm 0.22$ & $8.1 \pm 0.189$ & $1.5: 1$ & $1.4: 1$ \\
\hline 11 & $11.0 \pm 0.28$ & $11.6 \pm 0.36$ & $11.2 \pm 0.227$ & $6.5 \pm 0.28$ & $7.2 \pm 0.27$ & $6.8 \pm 0.216$ & $1.7: 1$ & $1.6: 1$ \\
\hline 12 & $10.6 \pm 0.46$ & $11.9 \pm 0.30$ & $11.2 \pm 0.301$ & $6.3 \pm 0.20$ & $6.5 \pm 0.14$ & $6.4 \pm 0.127$ & $1.7: 1$ & $1.8: 1$ \\
\hline 13 & $11.3 \pm 0.30$ & $10.9 \pm 0.44$ & $11.3 \pm 0.299$ & $7.3 \pm 0.33$ & $6.6 \pm 0.25$ & $7.0 \pm 0.22$ & $1.6: 1$ & $1.6: 1$ \\
\hline 14 & $11.5 \pm 0.35$ & $10.9 \pm 0.30$ & $11.2 \pm 0.241$ & $8.5 \pm 0.25$ & $7.9 \pm 0.41$ & $8.2 \pm 0.242$ & $1.4: 1$ & $1.4: 1$ \\
\hline 15 & $11.6 \pm 0.28$ & $12.2 \pm 0.33$ & $11.9 \pm 0.219$ & $8.6 \pm 0.23$ & $8.9 \pm 0.25$ & $8.7 \pm 0.17$ & $1.4: 1$ & $1.1: 1$ \\
\hline 16 & $10.4 \pm 0.35$ & $11.3 \pm 0.38$ & $10.8 \pm 0.273$ & $8.1 \pm 0.20$ & $8.4 \pm 0.25$ & $8.2 \pm 0.168$ & $1.2: 1$ & $1.3: 1$ \\
\hline 17 & $10.5 \pm 0.35$ & $11.0 \pm 0.44$ & $10.7 \pm 0.284$ & $7.7 \pm 0.20$ & $7.7 \pm 0.25$ & $7.7 \pm 0.152$ & $1.4: 1$ & $1.4: 1$ \\
\hline 18 & $10.1 \pm 0.25$ & $10.2 \pm 0.52$ & $10.3 \pm 0.276$ & $7.6 \pm 0.21$ & $7.8 \pm 0.33$ & $7.7 \pm 0.187$ & $1.4: 1$ & $1.3: 1$ \\
\hline er- & $10.7 \pm$ & $10.8 \pm 0.39$ & $10.16 \pm 0.41$ & $7.56 \pm 0.31$ & $7.64 \pm 0.29$ & $7.62 \pm 0.37$ & $1.43: 1$ & $1.4: 1$ \\
\hline
\end{tabular}

Assiut Vet.MedaJ. Vol. 18, No. 36, 1987. 
Table (3)

Body weight and daily weight gain in male and female Friesian calves Throughout the experimental period

\begin{tabular}{|c|c|c|c|c|c|c|c|c|}
\hline \multirow{3}{*}{$\begin{array}{l}\text { Age } \\
\text { mon. }\end{array}$} & \multirow{2}{*}{\multicolumn{2}{|c|}{$\begin{array}{l}\text { No. of } \\
\text { animals }\end{array}$}} & \multirow[b]{3}{*}{ Male } & \multirow{3}{*}{$\begin{array}{l}\text { Gain/day } \\
\text { male }\end{array}$} & \multirow[b]{3}{*}{ Female } & \multicolumn{2}{|c|}{ weight (Kg) } & \multirow{3}{*}{$\begin{array}{c}\text { Gain } \\
\text { overall } \\
\text { (kg / day) }\end{array}$} \\
\hline & & & & & & Gain/day & Overal & \\
\hline & $M$ & $F$ & & & & female & weight (Kg) & \\
\hline 1 & 15 & 15 & $42.4+0.88$ & - & $40.2+0.81$ & - & $41.3+0.616$ & - \\
\hline 2 & 15 & 15 & $63.6 \pm 2.68$ & 0.70 & $54.0+0.94$ & 0.42 & $58.3+2.136$ & 0.56 \\
\hline 3 & 15 & 15 & $84.0+3.50$ & 0.68 & $71.0 \pm 1.61$ & 0.60 & $77.5 \pm 2.254$ & 0.61 \\
\hline 3 & 15 & 15 & $84.0+3.50$ & 0.68 & $71.0 \pm 1.61$ & 0.60 & $77.5+2.254$ & 0.61 \\
\hline 4 & 15 & 15 & $106.2 \pm 2.50$ & 0.74 & $98.8+2.25$ & 0.92 & $102.5 \pm 1.818$ & 0.84 \\
\hline 5 & 15 & 15 & $131.0+3.69$ & 0.82 & $108.0+3.74$ & 0.306 & $119.5+3.367$ & 0.56 \\
\hline 6 & 15 & 15 & $144.3+3.10$ & 0.44 & $117.6+3.71$ & 0.32 & $131.0 \pm 3.44$ & 0.38 \\
\hline 7 & 15 & 14 & $156.3+3.51$ & 0.40 & $133.5+3.90$ & 0.53 & $140.5 \pm 3.401$ & 0.32 \\
\hline 8 & 15 & 13 & $168.3+3.69$ & 0.40 & $145.3+3.35$ & 0.39 & $157.6+3.377$ & 0.60 \\
\hline 9 & 15 & 13 & $180.0+3.30$ & 0.39 & $158.4+3.41$ & 0.43 & $169.2+3.498$ & 0.41 \\
\hline 10 & 15 & 13 & $194.0+5.00$ & 0.47 & $170.5+4.46$ & 0.40 & $182.2+4.121$ & 0.46 \\
\hline 11 & 15 & 13 & $211.3+4.97$ & 0.58 & $180.3+4.48$ & 0.32 & $195.8 \pm 4.545$ & 0.48 \\
\hline 12 & 15 & 13 & $237.3+5.21$ & 0.86 & $191.9+5.20$ & 0.38 & $214.6 \pm 5.76$ & 0.67 \\
\hline 13 & 15 & 13 & $260.6+5.28$ & 0.77 & $209.2 \pm 4.93$ & 0.57 & $234.9 \pm 6.173$ & 0.72 \\
\hline 14 & 15 & 13 & $285.0 \pm 5.97$ & 0.81 & $233.2+5.79$ & 0.77 & $258.6 \pm 6.614$ & 0.84 \\
\hline 15 & 15 & 13 & $309.6+697$ & 0.82 & $250.3+6.07$ & 0.60 & $279.9+7.411$ & 0.76 \\
\hline 16 & 15 & 13 & $334.6 \pm 7.12$ & 0.82 & $271.0+6.38$ & 0.69 & $302.6 \pm 7.776$ & 0.81 \\
\hline 17 & 15 & 13 & $357.6 \pm 7.12$ & 0.76 & $293.9+6.64$ & 0.76 & $325.7 \pm 7.913$ & 0.82 \\
\hline 18 & 15 & 13 & $389.3+7.48$ & 1.06 & $320.3+4.41$ & 0.88 & $354.8+8.346$ & 1.03 \\
\hline \multicolumn{3}{|c|}{ Overal mean } & & 0.67 & & 0.546 & & 0.62 \\
\hline
\end{tabular}

Table (4)

the correlation coefficient between body weight, calcium and inorganic phosphorus levels at different ages

\begin{tabular}{|c|c|c|c|c|}
\hline \multirow{2}{*}{$\begin{array}{l}\text { Age } \\
\text { mon. }\end{array}$} & \multicolumn{2}{|c|}{$\begin{array}{l}\text { Body weight } \\
\text { calcium }\end{array}$} & \multicolumn{2}{|c|}{$\begin{array}{l}\text { Body weight } \\
\text { inorganic } \mathrm{P} \text {. }\end{array}$} \\
\hline & Male & Female & Male & Fernale \\
\hline 2 & $-0.423 * *$ & $0.230^{* *}$ & $0.163 * *$ & $0.293 * *$ \\
\hline 4 & $0.259 * *$ & $-0.187^{* *}$ & 0.083 & -0.08 \\
\hline 6 & $-0.236^{* *}$ & $0.127 * *$ & $0.268 * *$ & $0.180^{* *}$ \\
\hline 8 & $0.172 * *$ & $0.603 * *$ & $0.473 * *$ & $0.512 * *$ \\
\hline 10 & $0.291 * *$ & $0.296 * *$ & 0.390 & 0.054 \\
\hline 12 & $0.527^{* *}$ & -0.039 & 0.023 & $-0.499 * *$ \\
\hline 14 & $-0.128^{* *}$ & $0.255^{* *}$ & 0.301 & $0.720 * *$ \\
\hline 16 & $0.199 * *$ & -0.033 & 0.039 & $0.515 * *$ \\
\hline 18 & $-0.128 * *$ & $0.091 *$ & $-0.525 * *$ & $0.242^{* *}$ \\
\hline
\end{tabular}

*: Significant at $P<\mathbf{0 . 0 5}$. 


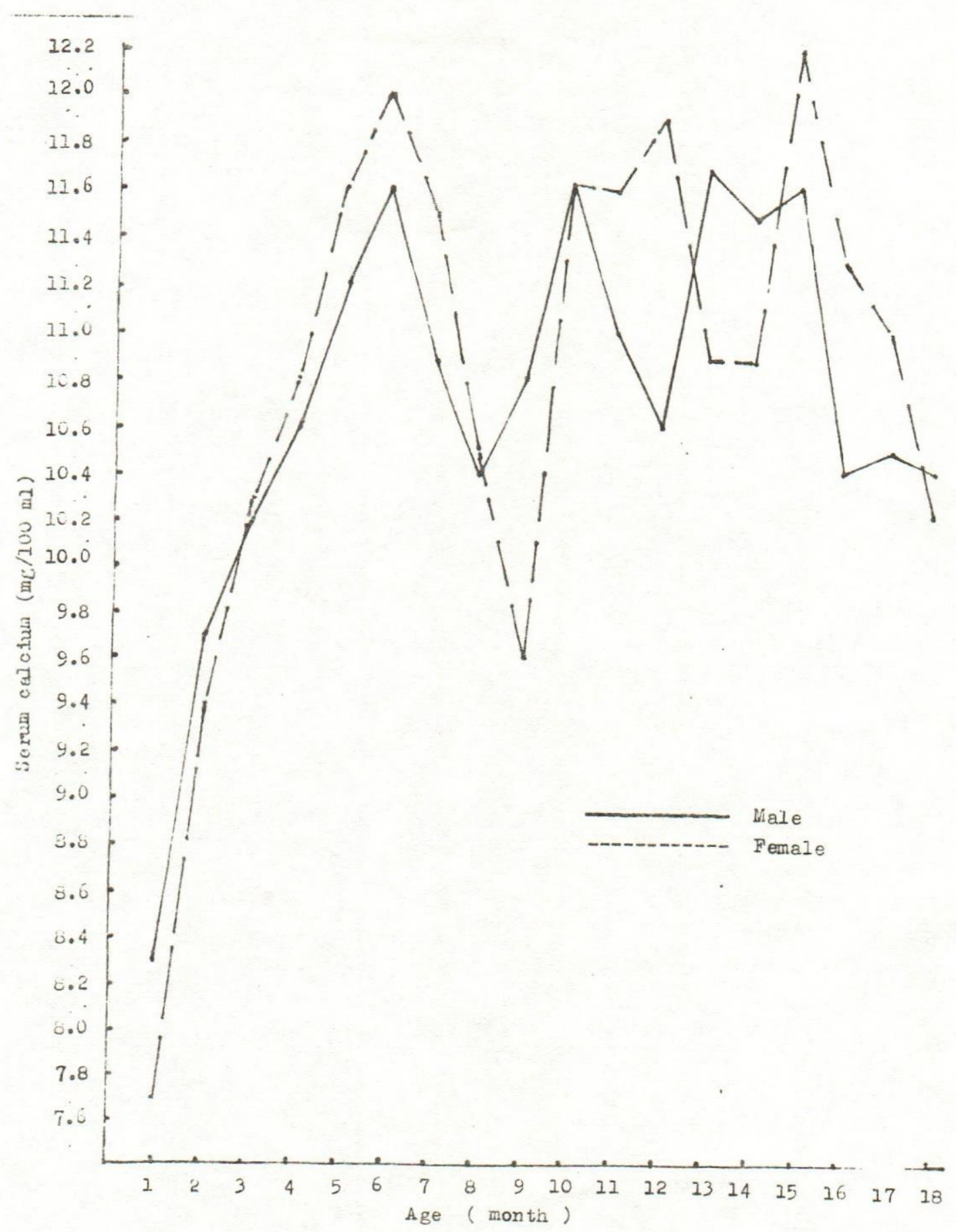

Fig. (I ): Serum calcium values in male and fomale Friesian calves at different ager. 


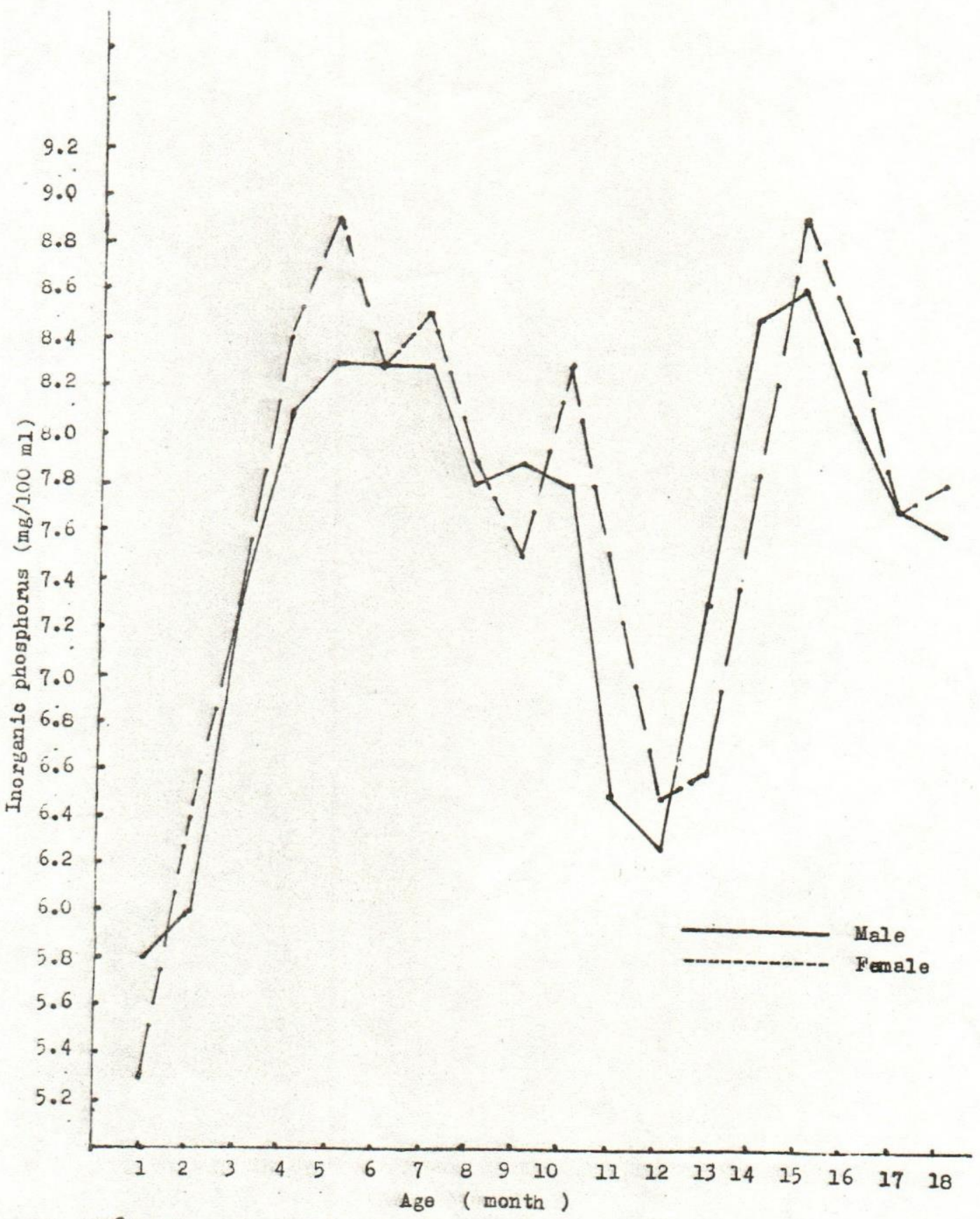

Fig. (2): Serum inorganic phosphorus values in male and female Friesian calvos at different ages. 


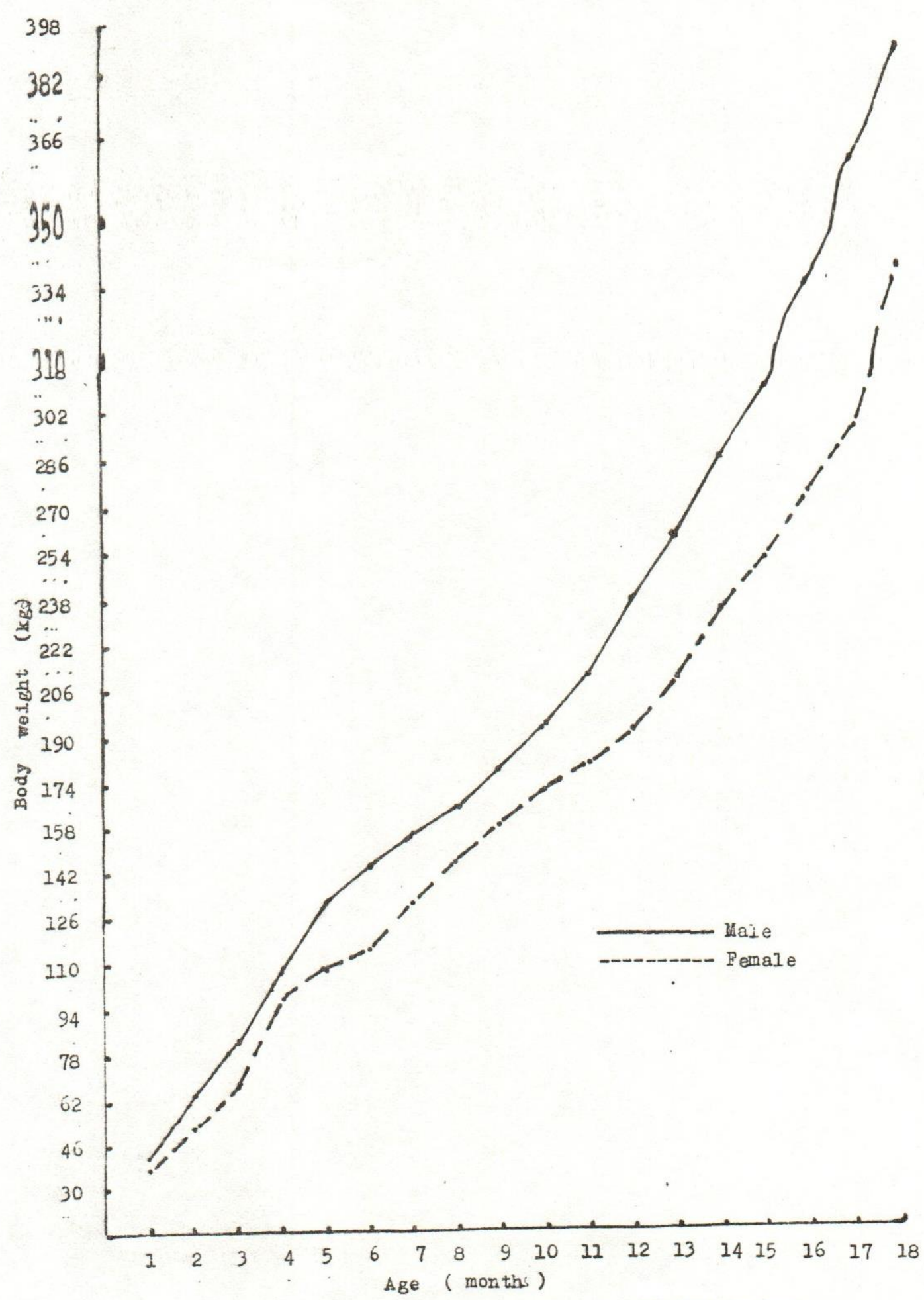

Fig. ( 3$)$ : Body weight $\left(\mathrm{k}_{B}\right)$ at different ages as affected by sex. 